\title{
CUSHING'S SYNDROME ASSOCIATED WITH BRONCHIAL CARCINOMA
}

Cushing's syndrome associated with malignant neoplasia is a rare disease; 51 cases are adequately recorded. Allott and Skelton (1960) reviewed all reported cases and added two of their own. Another 12 cases have been reported since (Bagshawe 1960, Parrish 1962, Vogel, Keating and Bohn 1961, Billinghurst, Thould, Galpin and Hinton 1961, Thompson, Horwick and Davis 1962, Meador, Liddle, Island, Nicholson, Lucas, Nuchton and Luetacher 1962). The present case is recorded because the diagnosis was suggested by hypokalæmia which was more severe than in any other case, and because it was complicated by diabetes mellitus.

\section{Case Report}

A 65-year-old woman (R.I. 24591) was admitted to the Radcliffe Infirmary on May 11th, 1962. Basing her opinion on the symptoms of diabetic relatives, she thought she had had diabetes for several years. There was a strong family history in that her mother and her mother's four sisters and brother had developed diabetes mellitus late in life, and her mother's brother's daughter had died of the disease at the age of four years.

For a year the patient had become progressively unwell, with increasing breathlessness on exertion and ankle œdema. Five weeks before admission she had developed pneumonia which had been successfully treated at home with penicillin and tetracycline; at that time her general practitioner had found glycosuria. Accordingly she was seen at the Diabetic Clinic three weeks before admission, where the diagnosis of diabetes mellitus was confirmed and treatment begun with a 1200 calorie diet.

Rapidly increasing chest signs over 36 hours, glycosuria, ketonuria and a tendency towards drowsiness led to her emergency admission.

On examination she was alert, had a plethoric complexion with increased pigmentation, a dorsal kyphosis, mild dehydration and signs of heart failure. Ankle and sacral odema were present and numerous coarse crepitations heard over both lung bases; JVP normal, BP 160/90 mm. Hg., pulse regular $75 / \mathrm{min}$. The liver was enlarged to 2 ins. below the right costal margin, hard and not tender. The urine contained sugar (orange with Clinitest) and a moderate amount of ketones.

Diagnoses of diabetes mellitus and congestive cardiac failure were made and treatment begun with soluble insulin, digitalis folia and mersalyl. The hæmoglobin was $18.5 \mathrm{~g} / 100 \mathrm{ml}$; PCV 52 per cent, WBC 10,900/cu.mm., normal differential; ESR 15 $\mathrm{mm}$./hr.

Clinical Course. About nine hours after admission she suddenly became very distressed, breathless and cynanosed with a rise in JVP and pulse rate to $150 / \mathrm{min}$.; the latter could be halved by pressure over the carotid sinus, and an ECG showed atriah flutter with a 2:1 block, which proved to be due to a profound hypokalæmic alkalosis: serum $\mathrm{K} \overrightarrow{0}$ $0.7 \mathrm{mEq} / 1 ; \mathrm{Na} 125 \mathrm{mEq} / \mathrm{l} ; \mathrm{Cl}<70$ $\mathrm{mEq} / 1 ; \mathrm{HCO}_{3}>40 \mathrm{mEq} / 1$. It had probably been enhanced by, but could not wholly be explainedp by, the treatment which by then constituted a totap of soluble insulin 40 units, digitalis folia gr. 6 and mersalyl $1 \mathrm{ml}$. The hypokalæmia was treated with. potassium chloride $2 \mathrm{~g}$. hourly for 7 doses by mouth, resulting in considerable clinical improve $f$ ment and cessation of the atrial flutter. Potassiumo chloride was continued in a dose of 2 g. q.d.s., andos blood electrolyte levels three days after admission were $\mathrm{K} 4.0 \mathrm{mEq} / 1 ; \mathrm{Na} 139 \mathrm{mEq} / 1 ; \mathrm{HCO}_{3} 35$ $\mathrm{mEq} / 1 ; \mathrm{Cl} 87 \mathrm{mEq} / 1$.

During the period of hospital treatment the heart failure was controlled by digitalis folia gr. 10 daily, and the dose of Lente Insulin was stablisheof at 32 units daily. Diuretics were not given except్
initially.

At first she improved, but then graduagy deteriorated, complaining of weakness and sleepiness she was very lethargic, sometimes confused, bruised easily, had persistent mild ankle odema, and a clearance of the coarse crepitations had continuap chest signs of diminshed resonance to percussions and fine crepitations at the right mid-zone posteriorly.

The recurring hypokalæmia was difficult to correc and increasingly large doses of potassium chloride were required. Large quantities of potassium werco being excreted in the urine. On a dose of potassium chloride $8 \mathrm{~g} /$ day the urinary output was equivalent to $9.6 \mathrm{~g} /$ day. In a speculative attempt to halve the potassium loss, Aldactone $400 \mathrm{mg}$. daily was com bined with potassium chloride $32 \mathrm{~g}$. daily, and on that treatrnent the serum potassium rose from $2.6 \rightrightarrows$ $\mathrm{mEq} / 1$ to $6.5 \mathrm{mEq} / 1$ after five days (31st day aftero admission). Because of the patient's poor genera condition the Aldactone was stopped and potassium chloride decreased to $8 \mathrm{~g} /$ day resulting in a precipitous fall in the serum potassium level to 3.1 $\mathrm{mEq} / 1$ the next day.

The excessive potassium loss had suggested the possibility of adrenal cortical hyperactivity? Although the typical obesity of Cushing's syndrome was absent the patient did have plethora with mild N polycythæmia on admission, increased pigmentation, a dorsal kyphosis, easy bruising, glycosuria $\mathcal{N}_{0}$ persistent ankle odema, a low serum protein of $5 \mathrm{~g} / 100 \mathrm{ml}$. and osteoporosis shown on X-ray of the spine. A 48-hour urine specimen gave the results :-

Output of average neutral ketosteroids

$31 \mathrm{mg} / 24 \mathrm{hr}$.

Average neutral ketogenic steroids $-92 \mathrm{mg} / 24 \mathrm{hr}$. T

Average 17-hydroxycorticoids $89 \mathrm{mg} / 24 \mathrm{hr}$.

The very high urinary steroid output and severeop 
hypokalæmic alkalosis strongly suggested that the Cushing's syndrome was the type associated with a malignant tumour. Several chest X-rays showed a persistently enlarged hilum of the right lung suggestive of a bronchial carcinoma. The diagnosis of malignancy was supported by a rise in ESR from $15 \mathrm{~mm}$./hr. to $101 \mathrm{~mm}$./hr. and a fall in hæmoglobin from $18.5 \mathrm{~g}$ to $10.1 \mathrm{~g} / 100 \mathrm{ml}$. over four weeks. A buffy-coat smear showed a leucoerythroblastic picture, and a bone marrow biopsy showed clumps of cells which had characteristics consistent with a metastasis from a carcinoma of the lung.

The diagnosis made was Cushing's syndrome associated with carcinoma of the lung, with secondary deposits in the bones and liver. The patient developed symptoms of a psychosis; she became severely depressed, had delusions of persecution and five days before death was in a catatonic stupor for 18 hours. After coming out of it she remained severely depressed and died five weeks after admission.

Post Mortem (Dr. M. Zahir). The left lung was congested and the right lung completely consolidated. The right lower lobe bronchus had a thickened ulcerated mucosa which appeared to be the primary site of the neoplasm, and the lobe itself was infiltrated with neoplastic tissue and contained numerous small abscesses. Histologically the neoplasm showed pleomorphism with sheets of "oat cells" alternating with aggregates of squamous cells. Metastases were present in the liver and lumbar vertebrae and showed uniform "oat cell" appearance. Both adrenals were markedly enlarged, the left weighing $30 \mathrm{~g}$, and the right $18 \mathrm{~g}$. The centres of both were very thick and deep yellow with prominent zonæ fasiculatæ; the left contained a nodule $2 \mathrm{~cm}$. in diameter which histologically did not show a well-defined margin and appeared to be hyperplastic in origin. The pituitary appeared to be small as it did not completely fill the pituitary fossa but it did not show any microscopic abnormality.

\section{Comment}

The neoplasm most commonly associated with Cushing's syndrome is bronchial carcinoma, being present in 27 out of the 51 cases.

As in most other cases of this type, the change in appearance of the patient was not so marked as in primary Cushing's syndrome. The diagnosis was first suggested by the hypokalæmia and supported by the clinical signs and the results of investigations showing many features of Cushing's syndrome and others of bronchial carcinoma; the presence of carcinoma was confirmed by bone marrow biopsy.

The extreme degree of hypokalæmia is worth emphasis. There was great difficulty in maintaining the patient in potassium balance and large doses of potassium chloride were necessary. Aldactone was given because of the possibility that the potassium loss was partly due to excess aldosterone secretion, which has been found in one out of nine cases where it has been estimated (Bagshawe 1960 ; Meador and others 1962). Aldactone seemed to be of value. Its effect cannot properly be determined, however, in this case, because the dose of potassium chloride was concurrently increased.

Liddle and others (1963) had produced evidence that the Cushing's syndrome is caused by a polypeptide which is biologically similar to pituitary adrenocorticotrophic hormone and which is secreted by the carcinoma.

I wish to thank Professor L. J. Witts for the help he has given me in preparing this paper.

\section{REFERENCES}

Allot, E. R., Skelton, M. O. (1960): Increased Adreno-cortical Activity, Associated with Malignant Disease. Lancet, ii, 278.

BAgShaWE, K. D. (1960): Hypokalæmia, Carcinoma and Cushing's Syndrome. Lancet, ii, 284.

Billinghurst, J. R., Thould, A. K., Galpin, O. P., Hinton, J. M. (1961): Carcinoma and Cushing's Syndrome. Brit. med. J., ii, 490 .

Liddle, G. W., Island, D. P., Ney, R. L., Nicholson, W. E., Shimizu, N. (1963). Non-pituitary Neoplasms and Cushing's Syndrome. Arch. intern. Med., 111, 47.

Meador, C. K., Liddle, G. W., Island, D. P., Nicholson, W. E., Lucas, C. P., Nuckton, J. C., LueTACHER, J. A. (1962): Cause of Cushing's Syndrome in patients with Tumours arising from "Nonendocrine Tissue". J. clin. Endocr. 22, 693.

PARrish, J. A. (1962): Hypokalæmia, Carcinoma and Cushing's Syndrome. Lancet, ii, 603.

Thompson, G. S., Horwick, L., DAvis, J. C. (1962): Carcinoma of Bronchus and Cushing's Syndrome. Lancet, ii, 534.

Vogel, M. D., Keating, F. R., Bohn, R. C. (1961): Cushing's Syndrome and Carcinoma of the Lung. Proc. Mayo Clin., 36, 387. 